\title{
Debris flows on forested cones - reconstruction and comparison of frequencies in two catchments in Val Ferret, Switzerland
}

\author{
M. Bollschweiler and M. Stoffel \\ Laboratory of Dendrogeomorphology, Department of Geosciences, University of Fribourg, Chemin du Musée 4, 1700 \\ Fribourg, Switzerland
}

Received: 16 October 2006 - Revised: 28 February 2007 - Accepted: 28 February 2007 - Published: 5 March 2007

\begin{abstract}
Debris flows represent a major threat to infrastructure in many regions of the Alps. Since systematic acquisition of data on debris-flow events in Switzerland only started after the events of 1987, there is a lack of historical knowledge on earlier debris-flow events for most torrents. It is therefore the aim of this study to reconstruct the debrisflow activity for the Reuse de Saleinaz and the La Fouly torrents in Val Ferret (Valais, Switzerland). In total, 556 increment cores from 278 heavily affected Larix decidua Mill., Picea abies (L.) Karst. and Pinus sylvestris L. trees were sampled. Trees on the cone of Reuse de Saleinaz show an average age of 123 years at sampling height, with the oldest tree aged 325 years. Two periods of intense colonization (the $1850 \mathrm{~s}-1880$ s and the 1930s-1950s) are observed, probably following high-magnitude events that would have eliminated the former forest stand. Trees on the cone of Torrent de la Fouly indicate an average age of 119 years.

As a whole, tree-ring analyses allowed assessment of 333 growth disturbances belonging to 69 debris-flow events. While the frequency for the Reuse de Saleinaz study site comprises 39 events between AD 1743 and 2003, 30 events could be reconstructed at the Torrent de la Fouly for the period 1862-2003. Even though the two study sites evince considerably different characteristics in geology, debris-flow material and catchment morphology, they apparently produce debris flows at similar recurrence intervals. We suppose that, in the study region, the triggering and occurrence of events is transport-limited rather than weathering-limited.
\end{abstract}

Correspondence to: $\mathrm{M}$. Bollschweiler

(michelle.bollschweiler@unifr.ch)

\section{Introduction}

Debris flows are fast flowing mixtures of water, gas and debris of different size, ranging from silt to boulders with diameters of several meters (Varnes, 1978). Depending on the composition of the material and the amount of water, individual surges can occur in the form of sediment-charged flooding or debris flows sensu stricto with very low water content and rigid flow behavior (Hungr, 2005). These flows generally occur during periods of intense rainfall (Caine, 1980; Corominas and Moya, 1999; Chen et al., 2006), rapid snowmelt (Wieczorek and Glade, 2005), a combination of these two triggering factors, or the breakout of a glacier lake (GLOF; Clague and Evans, 2000). Initiation of debris flows requires a sufficient amount of loose rock and soil deposits (Bovis and Jakob, 1999), steep slope, and a large supply of water (Wilson and Wieczorek, 1995). Once triggered, the material generally follows pre-existing channels and erodes their banks and beds (Bollschweiler et al., 2005) or deposits lateral levees on its way, where no erosion takes place. As soon as the slope angle or the water content of the mass decreases, the movement is stopped and material deposited in the form of terminal lobes (Major and Iverson, 1999). Repeated debris-flow activity at the same site leads to the formation of a debris-flow cone (Rapp and Nyberg, 1981; Takahashi, 1991; Hungr, 1995; Wilkerson and Schmid, 2003; Stoffel et al., 2006).

Trees growing on cones can be repeatedly affected by debris flows and react to such disturbances with growth anomalies. As a consequence, tree-ring records have repeatedly been used to identify the earlier occurrence of debris flows (Santilli and Pelfini, 2003; May and Gresswell, 2004; Stoffel and Beniston, 2006). Spatial patterns of debris-flow events have been assessed through the coupling of geomorphic mapping with tree-ring analyses (Bollschweiler et al., 2007). In a similar way, the magnitude of events has been

Published by Copernicus GmbH on behalf of the European Geosciences Union. 


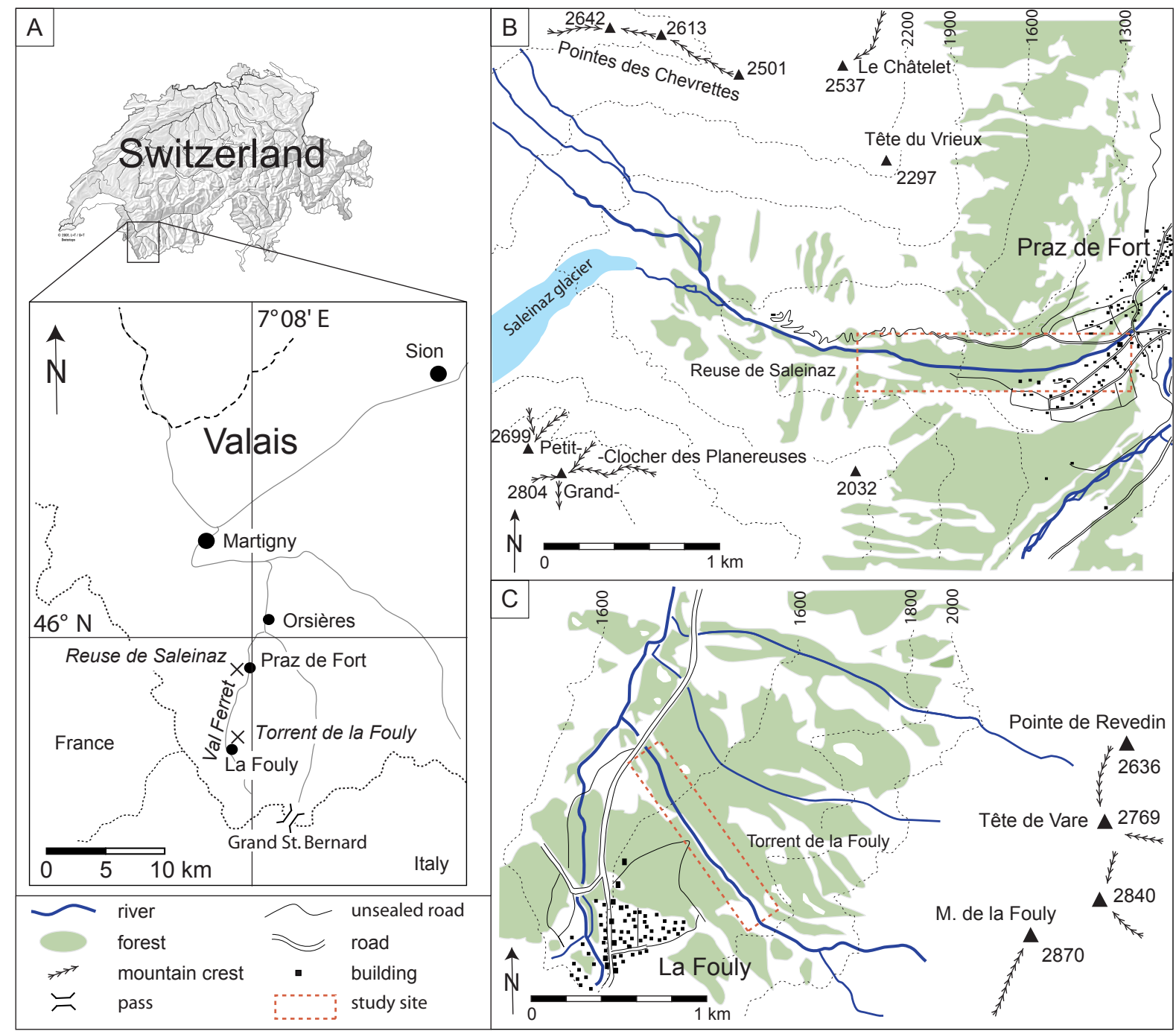

Fig. 1. (a) The two study sites are located in Val Ferret, south-western Swiss Alps. (b) The Reuse de Saleinaz catchment is located west of the village of Praz de Fort in the northern part of the valley. The map shows the catchment area with the Saleinaz glacier and the torrent's tributaries. (c) The sketch map of the Torrent de la Fouly shows the large debris-flow cone and the short distance between the catchment area and the cone's apex.

approximated by means of dendrogeomorphological methods (Strunk, 1997; Baumann and Kaiser, 1999; Van Steijn, 1996). Finally, Stoffel at al. (2005a) compared reconstructed debris-flow events with flooding data in neighboring rivers and lakes in order to investigate triggering weather conditions.

The aim of this study is to provide an overview of debrisflow activity in a Swiss Alpine valley through (i) the assessment of growth disturbances in trees growing on two debrisflow cones, (ii) a determination of events in the two torrents, (iii) the reconstruction of debris-flow frequencies and (iv) an illustration of the spatial activity of torrents during single events. In a final section, we discuss the reconstructed frequencies with archival data on flooding and debris flows in neighboring torrents.

\section{Study sites}

The Val Ferret has a surface of $115 \mathrm{~km}^{2}$ and is located in south-western Switzerland. The valley shares a border to the south with Italy and to the west with France (Fig. 1a). Except for its northern part, the valley is surrounded by high summits, with the highest elevation attaining $3901 \mathrm{~m}$ a.s.l. at Aiguille de l'Argentinière. The western slopes of the valley belong to the Mont Blanc Massif (Fig. 2) and are built of Paleozoic granite and intermittent bands of rhyolites (Labhart, 2004). The eastern slopes are located in geologically complex terrain, with the predominant upper units belonging to the Sion-Courmayeur zone (Mesozoic age) and the lower ones to ultrahelvetic layers of Jurassic age. The predominant rocks are flysch, black schists, calcareous schists and quarzites (Burri et al., 1992; Burri and Marro, 1993). 
Table 1. Characteristics of the two study sites.

\begin{tabular}{lcc}
\hline & Reuse de Saleinaz & Torrent de la Fouly \\
\hline altitudinal range of the cone (m a.s.l.) & $1150-1400$ & $1500-1740$ \\
cone area (ha) & 81 & 109.5 \\
altitudinal range of the catchment (m a.s.1.) & $1150-3901$ & $1500-2870$ \\
catchment area (ha) & 2135 & 113 \\
geology & Mont Blanc Massif (granite, rhyolite, gneiss) & Sion-Courmayeur zone (flysch, schist, quarzite) \\
predominant block size & $0.2-2 \mathrm{~m}$ & max. 0.5 m \\
\hline
\end{tabular}

The Reuse de Saleinaz (Fig. 1b; Table 1) is located in the western part of Val Ferret close to the village of Praz de Fort; its geology is dominated by the granites of the Mont Blanc Massif. The catchment area has a size of 2135 ha and extends from $3901 \mathrm{~m}$ a.s.1. (Aiguille de l'Argentinière) to the apex of the depositional cone of the Reuse de Saleinaz torrent at about $1400 \mathrm{~m}$ a.s.1. The upper part of the catchment is dominated by the Saleinaz and the Orny glaciers. The torrent originating at the Saleinaz glacier has its source at $2760 \mathrm{~m}$ a.s.1. and reaches the debris-flow cone after $1.5 \mathrm{~km}$. The torrent descending from the Orny glacier has its source at $2640 \mathrm{~m}$ a.s.1. and merges with the waters descending from the Saleinaz glacier at $1593 \mathrm{~m}$ a.s.l. Predominant rock sizes in the torrent are generally $>20 \mathrm{~cm}$ and smaller fractions are comparably scarce. The depositional cone of the torrent has an average slope angle of $7^{\circ}$ and extends from $1400 \mathrm{~m}$ a.s.l. to $1150 \mathrm{~m}$ a.s.1., with a surface of 81 ha. The cone is covered with European larch (Larix decidua Mill.), Norway spruce (Picea abies (L.) Karst.) and Scots pine (Pinus sylvestris L.). Anthropogenic influence on the cone is more pronounced on its southern side where deposits have been removed for housing construction. Apart from a small forest stretch located close to the torrent, the stand was eliminated for grazing activity over the past centuries. In contrast, the northern part of the cone is completely forested and human influence is non-existent, except for a road crossing the forest. In its lowermost part, debris-flow deposits were removed and the cone was reshaped for the construction of houses of the village of Praz de Fort in the 20th century. The area selected for analysis comprises both sides of the currently active torrent channel. South of the torrent, the entire stand was investigated. In the northern part, only trees located between the currently active channel and the road were chosen for analysis, as rockfall strongly influences tree growth close to the adjacent slope. Similarly, the uppermost part of the cone was omitted because of snow avalanche activity. For the Reuse de Saleinaz, six debris-flow events (1920, 1928, 1945, 1991, 1992 and 1993) are known in local archives (Rey and Saameli, 1997).

The Torrent de la Fouly (Fig. 1c; Table 1) is located in the eastern part of Val Ferret, and its geology dominated by the Sion-Courmayeur zone. The catchment has a size of 113 ha

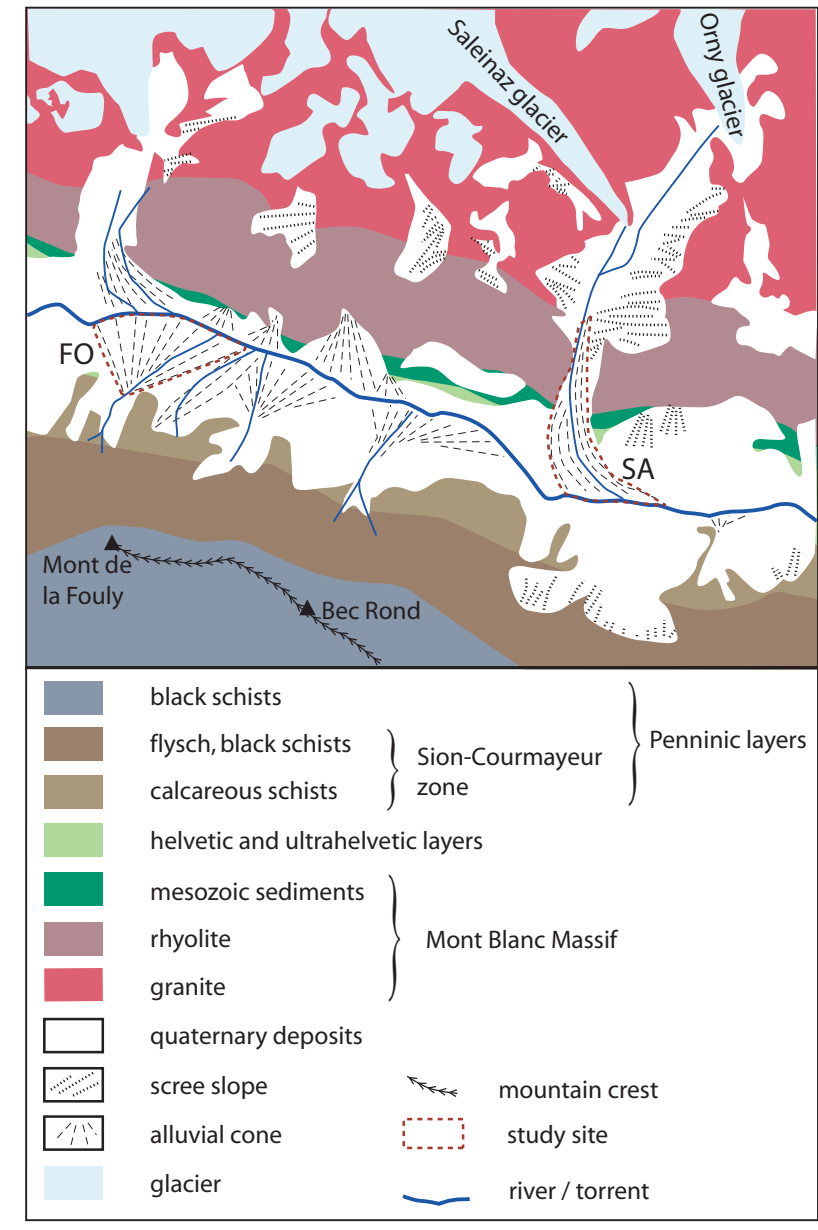

Fig. 2. Simplified geological map of Val Ferret. The debris-flow cones of two study sites Reuse de Saleinaz (SA) and Torrent de la Fouly (FO) are indicated by the red dotted line.

and there are no glaciers. The highest point of the catchment is Mont de la Fouly at $2870 \mathrm{~m}$ a.s.l. Material in the catchment is heavily fractured and readily available for the entrainment of debris flows. Two channels start at an elevation of about $2100 \mathrm{~m}$ a.s.l. They merge at $1846 \mathrm{~m}$ a.s.l. and reach the apex of the cone after a distance of only $250 \mathrm{~m}$. The debris-flow cone extends for 110 ha and has an average 
slope angle of $9^{\circ}$. The cone apex is located at $1740 \mathrm{~m}$ a.s.1. and the lower limit of the cone is at $1500 \mathrm{~m}$ a.s.l. where the Torrent de la Fouly flows into the Dranse river. The Dranse river influences neither the debris-flow cone nor the village of La Fouly. The forest stand on the cone consists mainly of $L$. decidua and $P$. abies. The village of La Fouly was built over the last few centuries on the debris-flow cone and occupies the distal parts of its surface towards the south. Within this study, trees were selected on both sides of the channel ( $20 \mathrm{~m}$ on each side). Farther away from the currently active channel, trees were normally too young and did not show any signs of past debris-flow activity. Archival data on past events are scarce, with only two debris-flow events recorded in 1991 and 1996 (Rey and Saameli, 1997).

\section{Material and methods}

\subsection{Field methods}

In a first step, a detailed geomorphic map on a scale of 1:1000 was established representing all forms related to debris-flow activity such as levees, lobes and previously active channels (Gaillard, 2006). This map served as a basis for the sampling strategy of trees growing in the deposits and obviously influenced by previous debris-flow events.

The basic assumption in dendrogeomorphological analysis is that a geomorphic event can be reflected in a tree's annual ring growth (Shroder, 1980; Giardino et al., 1984). Debris flows can affect trees in different ways (Schweingruber, 1996, 2001; Fig. 3): 1) A passing surge can cause abrasion at the tree stem. The tree reacts to this type of disturbance with changes in its cell structure and the formation of callus tissue as well as tangential rows of traumatic resin ducts (TRD; Stoffel et al., 2005b, c; Perret et al., 2006). 2) The unilateral pressure of the flow can lead to the inclination of the stem and the formation of compression wood on the downslope side of the trunk (Braam et al., 1987; Fantucci and SorrisoValvo, 1999; Stefanini, 2004). 3) The material of a debris flow can also bury the stem base, thus causing growth suppression (Strunk, 1997). 4) Similarly, trees may be decapitated by rocks or boulders transported in the debris-flow mass and react to such an impact with candelabra growth. 5) A distinct decrease in ring width can be observed in the years following the event. The elimination of neighboring trees can result in a growth release in the survivor trees (Strunk, 1997).

Within this study, we normally extracted two increment cores from each tree that presented evidence of debris-flow damage. The cores were taken according to the morphology of the stem: a) trees with scars were sampled close to the edges of the wound and on the downslope side of the stem; b) cores from tilted trees were taken at the height of the inclination and on the opposite side; c) decapitated trees or trees with a buried stem base were cored as close to the ground as possible. The position of each tree was marked precisely on the geomorphic map. At Reuse de Saleinaz, 228 trees were sampled, namely $148 \mathrm{~L}$. decidua, $31 \mathrm{P}$. abies and $49 P$. sylvestris. At Torrent de la Fouly, only 50 trees were sampled: 42 P. abies and 8 L. decidua trees.

In addition to the disturbed trees sampled on the cone, we selected undisturbed $L$. decidua and P. abies trees from a nearby forest stand, which showed no signs of debris-flow activity or other geomorphic processes. Reference chronologies were built so as to obtain information on "normal" (i.e. climate-driven) growth conditions at the two locations (Cook and Kairiukstis, 1990). For both study sites, at least 15 trees per species were sampled.

\subsection{Laboratory methods}

In the laboratory, samples were analyzed following the procedure described by Bräker (2002). Individual working steps included the sanding of increment cores and measurement of tree-ring widths using a LINTAB measuring device and TSAP software (Time Series Analysis and Presentation; Rinntech, 2006). Growth curves of disturbed trees were crossdated with the corresponding reference chronology so as to identify missing or faulty tree rings (Schweingruber, 1996). Tree samples were then analyzed visually using a binocular. Anatomical changes such as TRD, the onset of reaction wood or callus tissue were noted on skeleton plots (Schweingruber et al., 1990), before growth curves were compared to the reference chronology in order to determine the beginning of growth suppression or release.

The age structure of the stands was assessed by means of the age of the selected trees. Since trees were not cored at the stem base and piths were not always present, the age structure does not reflect inception or germination dates of trees, but provides an appropriate image of the age distribution of the trees sampled. At Reuse de Saleinaz, an interpolation of tree age was produced in order to obtain a reasonable spatial illustration of the age distribution of trees. At Torrent de la Fouly, the number of sampled trees was too small for interpolations.

Events were defined by assessing the growth disturbances in the samples, their position within the debris-flow deposits as well as the spatial distribution of all trees showing growth disturbances (GD) in the same year. For all events, a map of the spatial distribution of affected trees was created. The position of all trees showing GD to a specific event was precisely marked on the geomorphic map so as to gain an idea on the spatial pattern of past debris-flow events.

Finally, the reconstructed debris-flow frequencies of Reuse de Saleinaz and Torrent de la Fouly were compared with each other as well as with archival data on debrisflow and flooding events in neighboring torrents (Rey and Saameli, 1997). 


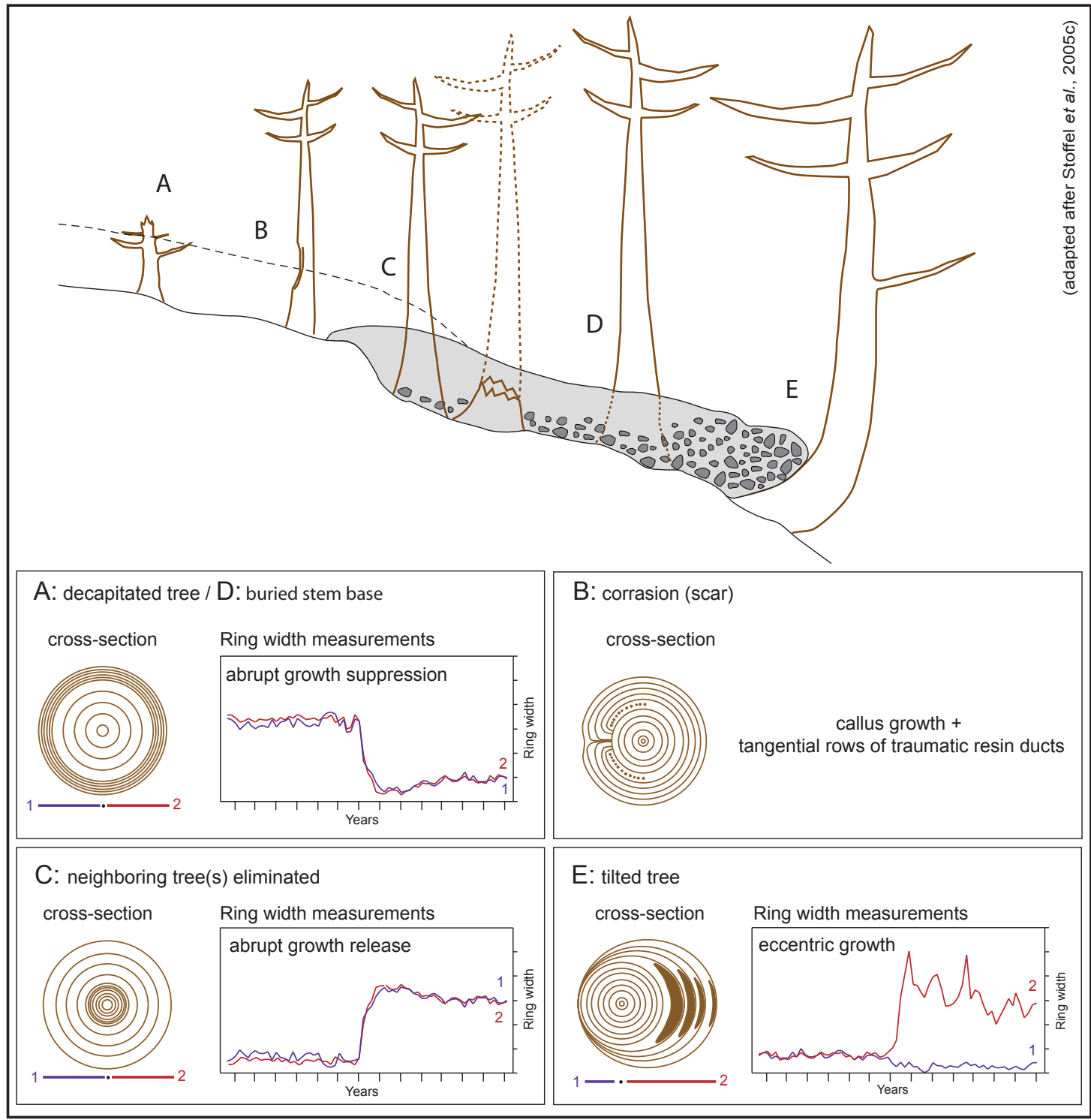

Fig. 3. Types of growth disturbances of trees affected by a debris-flow event.

\section{Results}

\subsection{Age structure of the stands}

The mean age at sampling height of the trees cored at Reuse de Saleinaz is 123 years: L. decidua trees are normally older, with an average age of 158 , while $P$. abies trees show, on average, 128 tree rings at sampling height. $P$. sylvestris trees are, in general, younger with only 90 increment rings on average. The age distribution within the stand is illustrated in Fig. $4 \mathrm{a}$ and proves to be quite heterogeneous. The oldest trees are located on the central part of the cone and north of the currently active channel; they reveal an age of 325 years (Table 2). In contrast, trees in the upper part of the cone are of much younger age, ranging from 50 to 60 years. Trees growing in the southern sectors of the cone show a similar pattern: the oldest trees can again be identified in the central part of the cone with ages reaching up to 250 years; trees in the upper part are much younger, with ages of about 100 years. It can be seen clearly from Fig. $4 \mathrm{~b}$ that the cone was actively colonized between 1850 and 1880 as well as between 1930 and 1950 .

At Torrent de la Fouly, the mean age of trees is 119 years. Again, L. decidua trees proved to be the much older here with a mean age of 148 years. In contrast, $P$. abies trees counted, on average, only 113 tree rings. The oldest tree sampled indicates an age at sampling height of 238 years, but only two trees are older than 170 years. The age distribution of all 


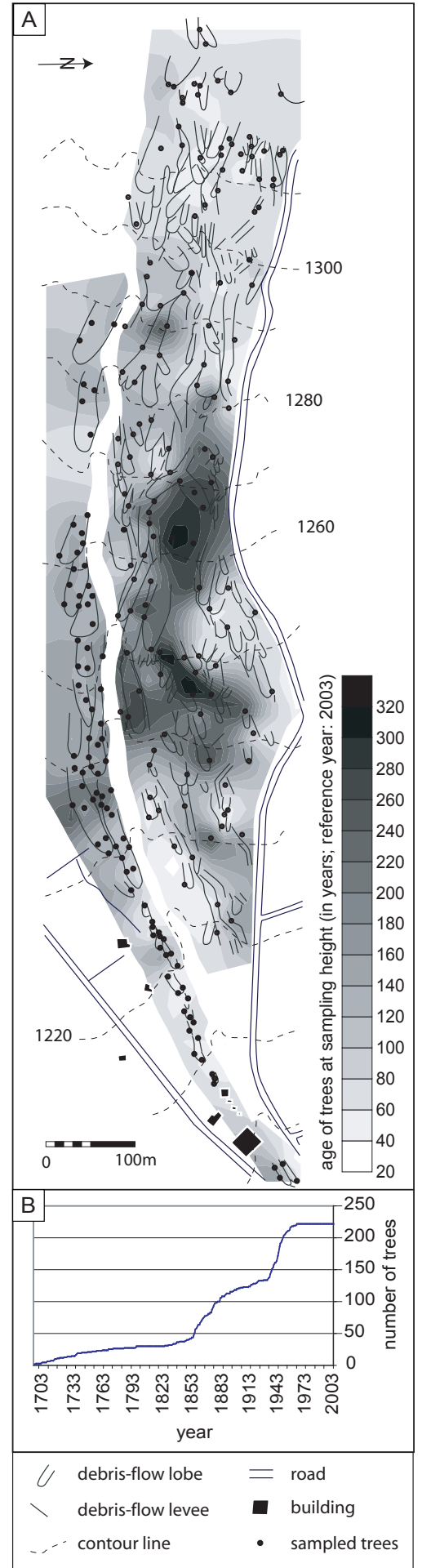

Fig. 4. (a) Age structure of the forest stand on the cone of the Reuse de Saleinaz. The oldest trees are located on the central part of the cone, whereas trees on the eastern sectors are rarely older than 60 years. The oldest tree reached sampling height in AD 1678. (b) Number of trees cored present in a given year.
Table 2. Statistics on tree ages (in years) for the two study sites.

\begin{tabular}{lcc}
\hline & Reuse de Saleinaz & Torrent de la Fouly \\
\hline mean & 123 & 119 \\
minimum & 40 & 37 \\
maximum & 325 & 238 \\
STDEV & 73 & 43 \\
\hline
\end{tabular}

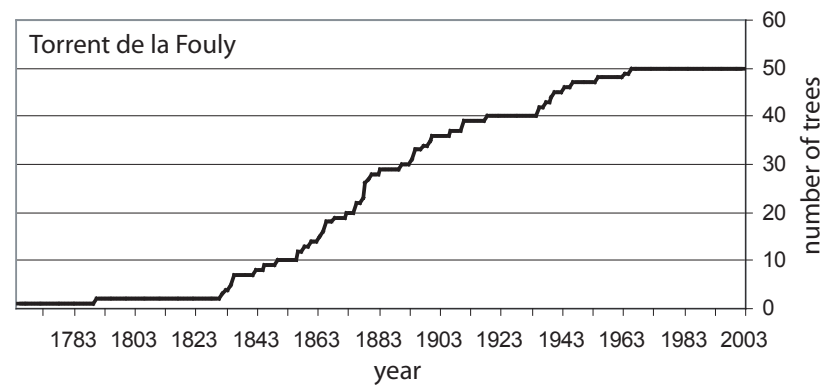

Fig. 5. Age structure of the trees sampled at Torrent de la Fouly. The oldest tree reached sampling height in AD 1765.

trees shows a regular increase in the number of trees, without any obvious period with higher germination rates (Fig. 5). The spatial age distribution indicates that the oldest trees can be found on the uppermost part of the cone.

\subsection{Dating of past debris-flow events}

In total, 333 growth disturbances (GD) were assessed in the 278 trees sampled at the two study sites. Table 3 provides an overview of the different GD identified, as well as the absolute and the relative numbers for each type of disturbance. At both study sites, tangential rows of traumatic resin ducts (TRD) represent the GD that could most frequently be identified on the increment cores with $82 \%$ and $65 \%$ of all reactions. While compression wood was only rarely assessed at Reuse de Saleinaz (3\%), it was more commonly identified in the samples collected at Torrent de la Fouly with 13\% of all GD. Growth suppression was used to date past debrisflow events in 9\% (Reuse de Saleinaz) and 16\% (Torrent de la Fouly) of samples, whereas growth release amounted to $5 \%$ of samples at both study sites. Injuries could, in contrast, only rarely be identified on the increment cores.

Figure 6 provides characteristic examples for the dating of a debris-flow event. The L. decidua tree illustrated in Fig. 6a is located in a debris-flow lobe in the lowermost part of the Reuse de Saleinaz cone and was partially buried by debris-flow material. Its growth curves show distinct growth suppression following a disturbance in 1991. The P. abies tree illustrated in Fig. $6 \mathrm{~b}$ grows in the front of a terminal lobe on the Torrent de la Fouly cone. It was tilted in 1962 and reacted to this disturbance with the formation of compression 
Table 3. Growth disturbances (GD) assessed in the 556 Larix decidua Mill., Picea abies (L.) Karst. and Pinus sylvestris L. samples. For both study sites as well as the entire sampling, the number (no.) as well as the percentages (\%) are indicated.

\begin{tabular}{lcccccc}
\hline & \multicolumn{2}{c}{ Reuse de Saleinaz } & \multicolumn{2}{c}{ Torrent de la Fouly } & \multicolumn{2}{c}{ Total } \\
& no. & $\%$ & no. & $\%$ & no. & $\%$ \\
\hline tangential rows of traumatic resin ducts & 208 & 82 & 52 & 65 & 260 & 78 \\
growth suppression & 22 & 9 & 13 & 16 & 35 & 11 \\
growth release & 13 & 5 & 4 & 5 & 17 & 5 \\
compression wood & 7 & 3 & 10 & 13 & 17 & 5 \\
injuries & 3 & 1 & 1 & 1 & 4 & 1 \\
\hline Total & 253 & 100 & 80 & 100 & 333 & 100 \\
\hline
\end{tabular}
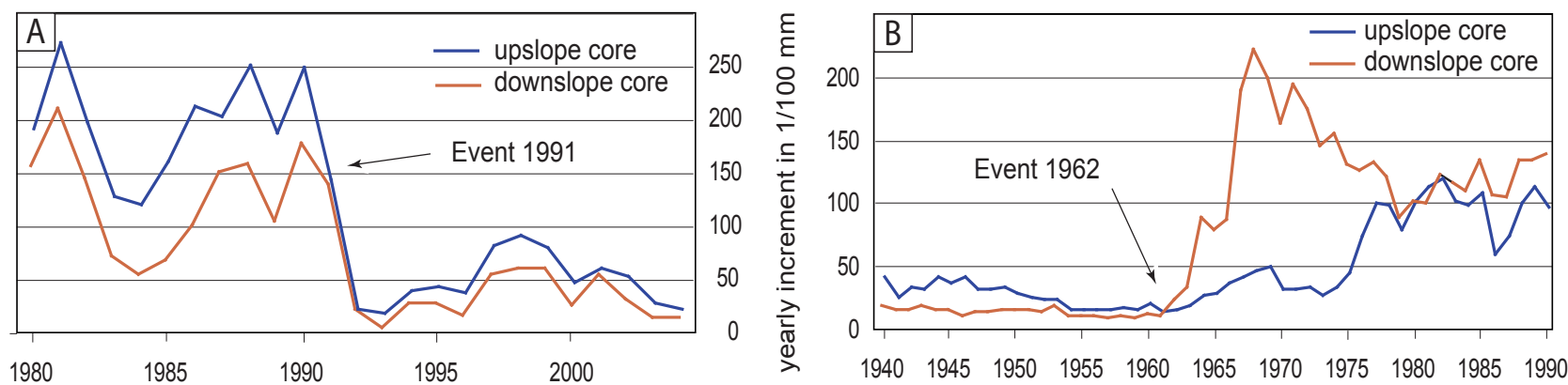

Fig. 6. Examples of growth disturbances in tree-ring series as a result of debris-flow activity: (a) This L. decidua shows abrupt growth suppression following an event in 1991. (b) The growth curves of this P. abies exhibit eccentric growth following an event in 1962. In addition, compression wood can be identified on the downslope core of this tree.

wood. The growth of this tree was strongly eccentric after 1962, as it produced much wider year rings on its downslope side than on the upslope side in the years following the event.

4.3 Reconstructed debris-flow frequencies at Reuse de Saleinaz and Torrent de la Fouly

The analysis of the 253 GD identified in the 456 tree-ring series sampled at Reuse de Saleinaz allowed identification of 39 debris-flow events, with the oldest event dated to $\mathrm{AD}$ 1743 (Fig. 7a). The number of events dated to the period $1743-1850$ is rather limited, with evidence of only six debris flows. Thereafter, the frequency becomes much higher with 33 events reconstructed between 1868 and 2003. From the data, it also appears that periods with repeated debris-flow activity are followed by phases with little or almost no activity. Such a clustering of events is especially obvious in the 1870 s, the early 1920 s or the 1970 s. As far as the six debrisflow events recorded in the local archives are concerned, four of them could be recognized in this study through dendrogeomorphological methods. In contrast, tree-ring records did not show any GD for the events that occurred in 1992 and 1993.

At Torrent de la Fouly, the identification of $80 \mathrm{GD}$ allowed reconstruction of 30 events for the period 1862-2003
(Fig. 7b). According to our results, debris flows recurred at more or less regular intervals, and we could identify periods characterized by notable or negligible activity. A clustering of events can be observed between 1945 and 1955, and again in the early 1960s. In contrast, none of the debris-flow events known in the local archives could be recognized by analyzing the tree-ring series.

\subsection{Spatial distribution of trees affected by debris-flow events}

The spatial distribution of trees affected by the same event is of considerable help in determining the minimum spatial extent of past debris flows. We present results for the Reuse de Saleinaz only, as the number of trees sampled at Torrent de la Fouly was too small for this kind of interpretation. The examples provided in Fig. 6 clearly indicate that individual events normally did not affect the entire cone but that they were limited to certain parts of the study area. In 1952 (Fig. 8a), a debris-flow event affected trees growing on the uppermost part of the cone. The spatial distribution of trees disturbed by a debris-flow event in 1962 (Fig. 8b) is quite similar. In contrast to the event in 1952, GD are restricted to trees growing close to the channel or on the outermost part of the cone, but not on its central part. Figure $8 \mathrm{c}$ provides 


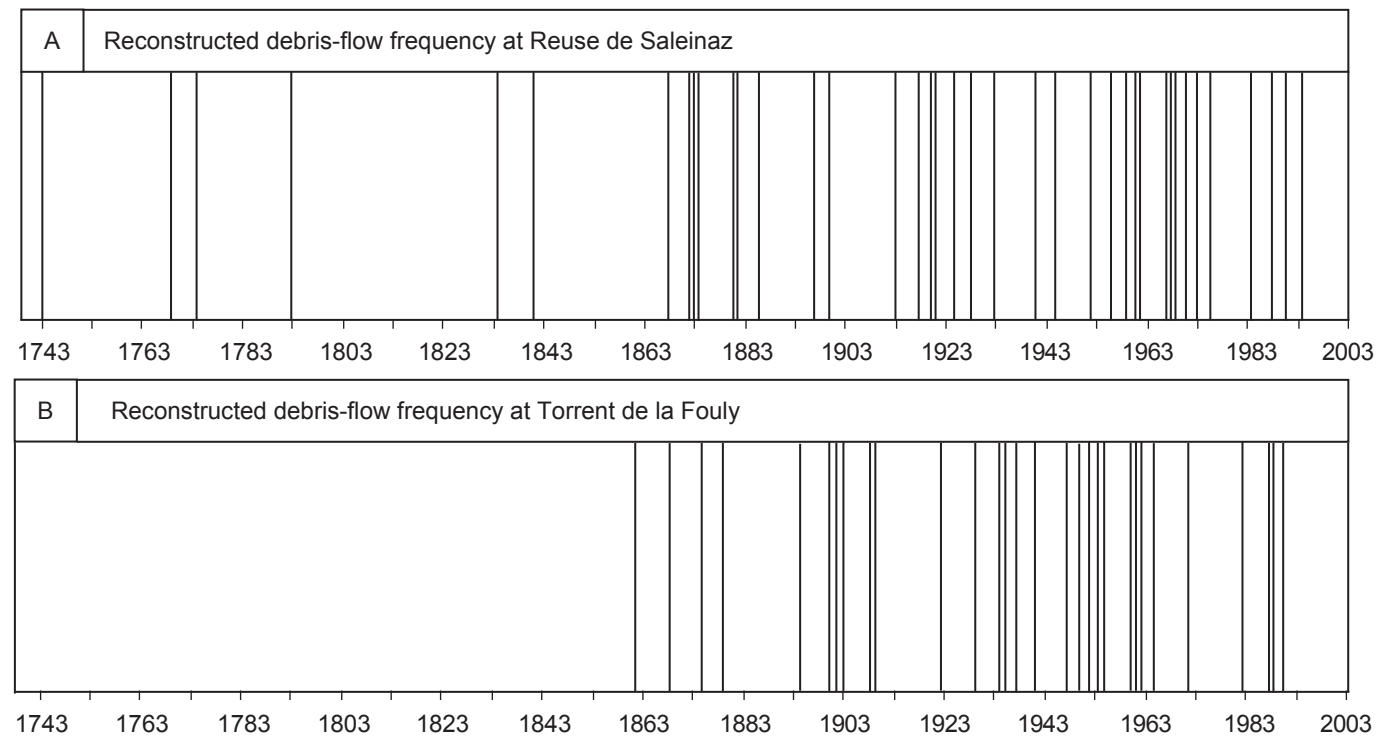

Fig. 7. (a) Reconstructed debris-flow frequency for the Reuse de Saleinaz with 39 events between AD 1743 and 2003 . (b) At Torrent de la Fouly, 30 events could be identified between AD 1862 and 2003.

an example from an event that influenced trees on the central part of the cone, where trees are old enough to record the event of 1834. Finally, Fig. 8d represents an event where material left the currently active channel in the lowermost part of the cone and affected trees south of the channel.

\subsection{Comparison of reconstructed events with data on flood-} ing in neighboring torrents in Val Ferret

The debris-flow events reconstructed by means of dendrogeomorphological methods in this study were compared to debris-flow and flooding events recorded in local archives (Rey and Saameli, 1997). For each event, all torrents producing a debris-flow or flooding event were noted on a map of the entire valley in order to represent the spatial extent of the event. Based on this representation, it appears that there are at least two different types of events (Fig. 9). During some events, activity was restricted to only one or a few torrents (Fig. 9a). On the other hand, there is also evidence for simultaneous debris-flow activity in a majority of torrents. For instance and as illustrated in Fig. 9b, nearly all torrents descending the eastern slopes of Val Ferret (with the exception of Torrent de Ferret and Combe à Paron) produced debris flows in August 1991.

\section{Discussion}

In this study, increment cores extracted from 278 living European larch (Larix decidua Mill.), Norway spruce (Picea abies (L.) Karst.) and Scots pine (Pinus sylvestris L.) trees allowed recognition of 333 growth disturbances (GD) caused by 69 debris-flow events. While, at Reuse de Saleinaz, 39 separate events could be identified since AD 1743, the reconstruction at Torrent de la Fouly covers 142 years and yields data on 30 events.

For both study sites, the number of reconstructed debrisflow events must be seen as a minimum frequency, as the reconstruction of past events was limited by the age of the trees. In this sense, all events that occurred prior to AD 1680 do not appear in the reconstruction due to the absence of trees showing more than 325 tree rings at sampling height. The limited number of trees available prior to the 1850 s may influence the quality of the reconstructed frequencies as well. Finally, debris flows remaining in the channel do not necessarily affect trees and may therefore not be identified by means of tree-ring analysis either. This fact is supported by archival data on the events of 1992 and 1993 in the Reuse de Saleinaz. The events could not be identified with dendrogeomorphological methods since surges apparently did not leave the current channel but, rather, caused erosion in the channel bed (Rey and Saameli, 1997).

The age structure of the forest stand at Reuse de Saleinaz clearly shows that the oldest trees can be found in the central part of the cone, whereas trees in the upper and lower parts are much younger. Trees growing in the uppermost part of the cone would be regularly eliminated by debris flows or rare snow avalanche activity; therefore, this sector has not been taken into account in the present study. In contrast, trees growing in the central part of the cone seem to be somehow more protected from geomorphic influence and anthropogenic activity. Geomorphic forms as well as the vegetation indicate that snow avalanches did not reach this part of 


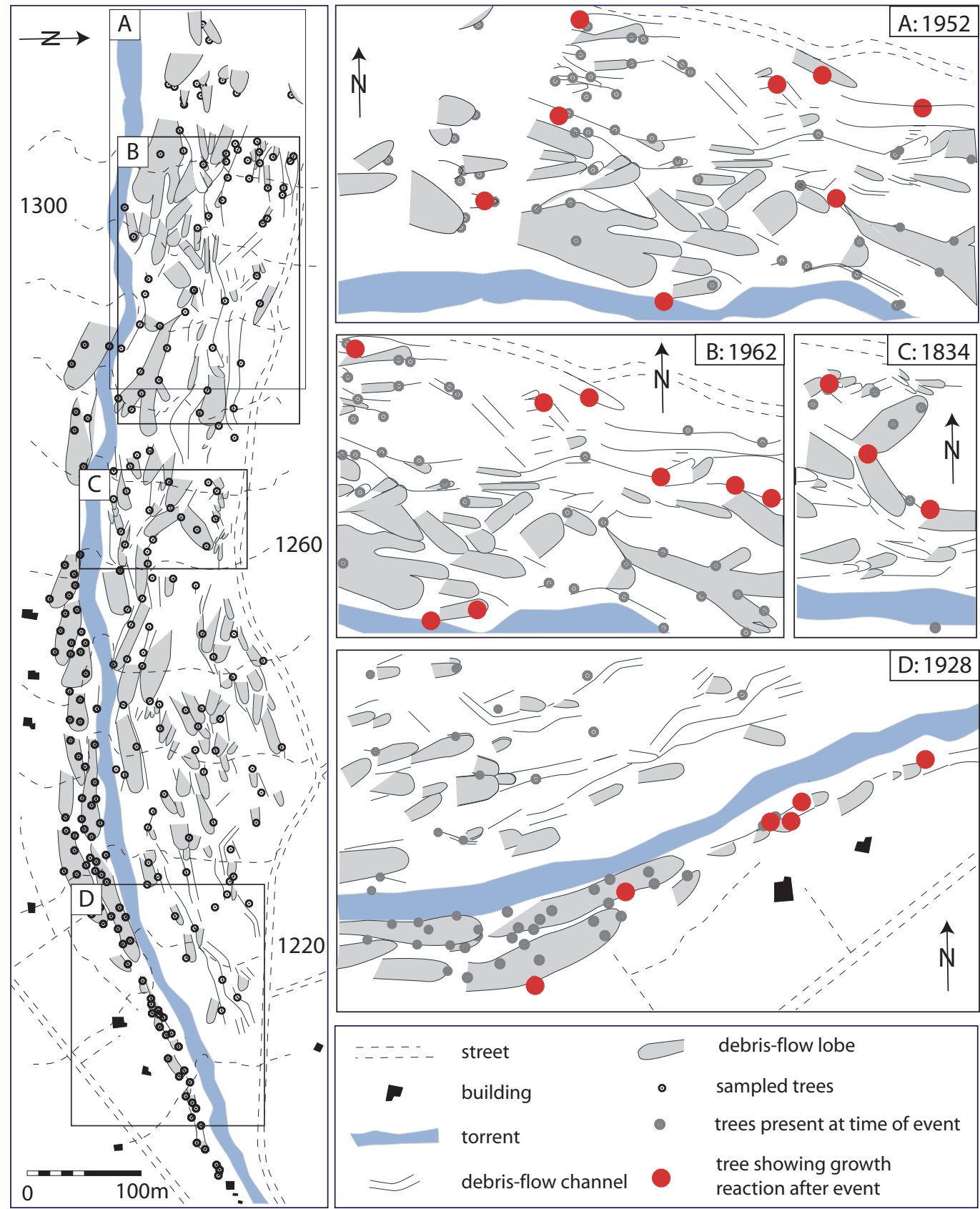

Fig. 8. Spatial distribution of trees at the Reuse de Saleinaz cone showing growth disturbances in (a) 1952, (b) 1962 , (c) 1834 and (d) 1928.

the cone. Anthropogenic interventions would influence the age and succession rates of trees in the lowermost part of the cone (i.e. farming activities, extraction of fire- and construction wood). Given that tree age is the main limiting factor for the reconstruction of debris-flow events using dendrogeomorphological methods, the approach works best at study sites where anthropogenic influence is small and timber harvesting has been infrequent in the past few centuries.
The age structure also indicates two periods with considerable colonization between 1850 and 1880 as well as between 1930 and 1950. A previous forest growing at this location might have been eliminated by exceptionally large or destructive debris-flow events. Dendrogeomorphological data allowed reconstruction of a major event in 1841. Given that tree age was determined at sampling height and therefore does not give information on germination dates, it is feasible that the tree succession in the 1850 s- 1880 s reflects a 

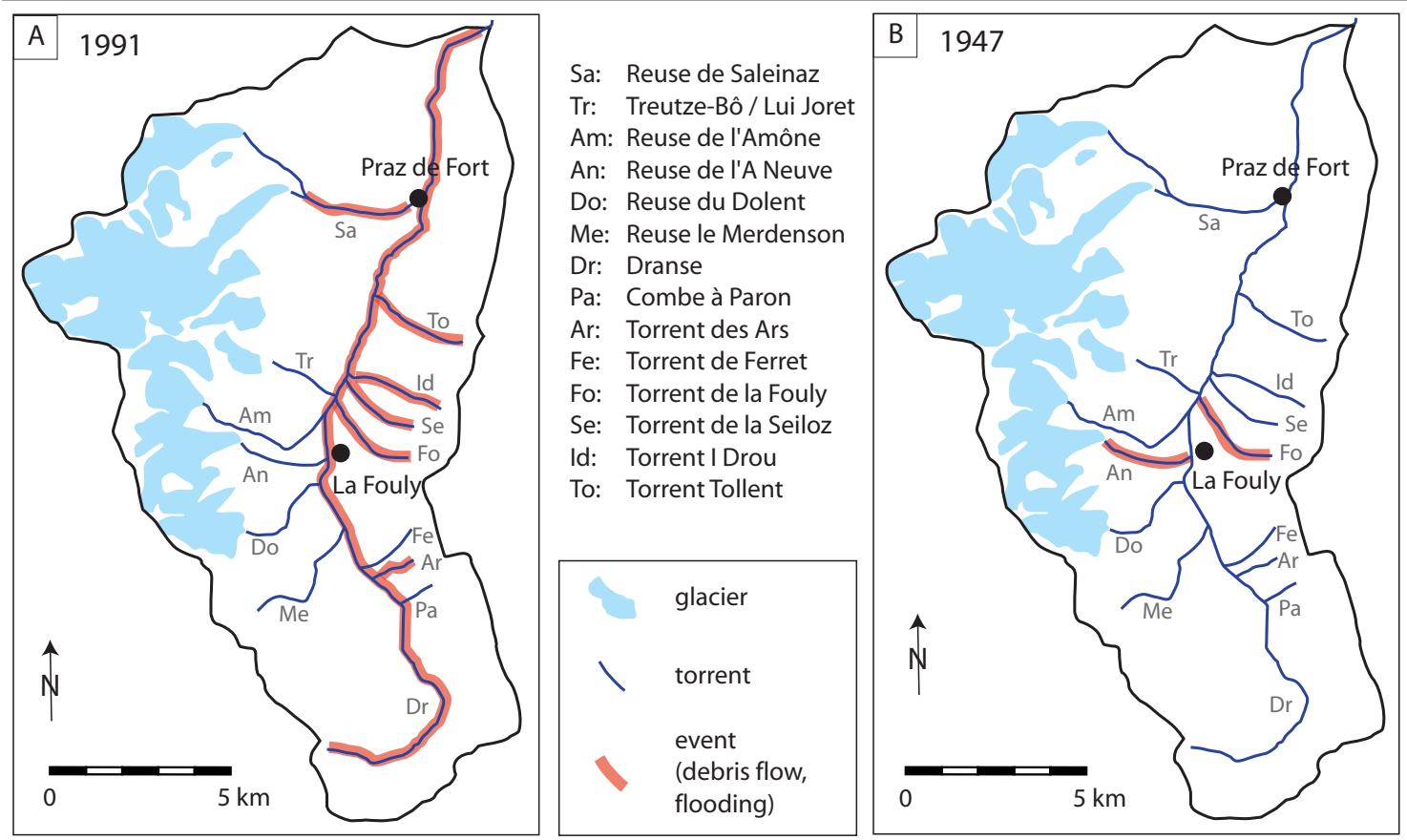

Fig. 9. (a) Spatial distribution of debris flows and flooding triggered in large parts of the Val Ferret by persistent rainfall in 1991. (b) In contrast, only the Reuse de l'A Neuve and the Torrent de la Fouly produced debris flows during a local summer thunderstorm in 1947 (archival data: Rey and Saameli, 1997).

re-colonization of the cone following the event in 1841 (see Fig. 5a). This assumption is further supported by analyses of the spatial distribution of survivor trees showing GD in 1841 as well as by the position of trees germinating in the years following this event. The second period with considerable tree succession on the cone during the 1940s is limited to the uppermost part of the cone. On the basis of our reconstructions, we assume that a previous forest stand would have been destroyed by the substantial debris-flow activity in the 1920s, resulting in increased re-colonization starting in the 1930s.

In contrast, the trees bordering the currently active channel at Torrent de la Fouly do not show abrupt steps in their age structure. It is possible that the limited number of trees chosen for analysis is the reason for this absence of colonization periods here. Another explanation might be the smaller rock sizes present in the catchment area. Individual surges and presumably smaller events may have caused GD to trees but did not eliminate entire sectors in the past.

Jakob et al. (2005) highlighted the importance of channel recharge rates in the triggering of debris-flow events. At Torrent de la Fouly, small rocks are readily available and debris supply cannot be considered a limiting factor here. In contrast, rock sizes at Reuse de Saleinaz are dominated by boulders and small fractions are less readily available. Nonetheless, the reconstructed frequencies at Torrent de la Fouly and Reuse de Saleinaz appear to be very similar, with an average of one event identified every eight years for the period of reconstruction. This similarity in the frequency of events should, however, be interpreted with caution, as the reconstruction at Torrent de la Fouly was considerably limited by the small number of trees suitable for dendrogeomorphological analysis. In addition, the currently used channel has probably been active for at least several decades. It is deeply incised, and may, thus, have prevented a certain number of high-frequency small-magnitude events from leaving the channel and from affecting trees located on the banks or on the cone. Finally, debris-flow activity at Torrent de la Fouly appears to be only influenced by meteorological events, whereas glacier-lake outburst flooding (GLOF) triggered debris flows at Reuse de Saleinaz in 1920 and 1928 (Rey and Saameli, 1997).

The spatial distribution of trees affected during particular events indicates that debris flows are normally restricted to only some parts of the cone. Although different patterns of debris-flow activity have been identified on a forested cone in the Valais Alps (Bollschweiler et al., 2007) such patterns could not be identified at Reuse de Saleinaz. It therefore seems that each event had its own characteristics and - except for the events remaining in the main channel - its own flow path. The limited number of channels and levees identified on the cone as well as the considerable number of lobate structures identified on the cone support this assumption. We therefore believe that as soon as previous debris flows left the 
main channel at Reuse the Saleinaz, the rough and porous surface of the cone caused surges to stop within a short distance. Based on the analysis of the deposits identified in the field, we also believe that only surges containing smaller rock sizes traveled to the northern and to the lowermost part of the cone.

A comparison of reconstructed events at Reuse de Saleinaz and Torrent de la Fouly with archival data on debris-flow and flooding activity in neighboring torrents reveals the existence of different spatial patterns of events. On the one hand, we identify debris flows and floods in a large number of torrents in Val Ferret that must have been triggered by persistent rainfall events affecting the entire valley. On the other hand, there is also evidence for more locally limited summer thunderstorms with debris flows and flooding in a very limited number of torrents. These observations need, however, to be interpreted very cautiously, as earlier events were only noted in archives if they caused major damage to infrastructure or even loss of lives. In a similar way, we observe an increase in debris-flow events noted in archives over the last century. Due to the changes in the awareness of the threats posed by debris flows and the enlargement of villages in Val Ferret, there is much high-quality information available on debris-flow events for the last two decades, whereas archival data remain comparably scarce for the early 20 th century.

\section{Conclusions}

Tree-ring analysis in two Alpine catchments located in Val Ferret (south-western Switzerland) allowed reconstruction of 39 events at Reuse de Saleinaz and 30 events at Torrent de la Fouly. The reconstruction for the Reuse de Saleinaz covers 260 years. In contrast, tree age at Torrent de la Fouly limited the reconstruction to 141 years. Although the two investigated torrents possess different predisposition characteristics to debris flows, their debris-flow frequency is very similar, with one event every eight years on average. Therefore, we suppose that the recurrence of events for both torrents depends on precipitation events and thus has to be considered rather transport-limited than weathering-limited. The spatial distribution of trees that have been disturbed during earlier events indicates that events normally affected only a part of the cone. In addition, no characteristic patterns of spatial behavior could be identified. Therefore, we believe that surges leaving the currently active channel stopped after a short travel distance. Even though the age of trees growing on the cone limited the reconstruction, dendrogeomorphological methods proved to be a valuable tool to gain information on former debris-flow events at the study sites.

Acknowledgements. The authors are grateful to Nicole Gaillard, Kathrina Steffen and Frederic Auderset for all manner of assistance in the field and the lab. Prof. Michel Monbaron's financial and moral support is also gratefully acknowledged. We would like to thank Dominique Schneuwly for insightful comments on an earlier version of the manuscript. Heather Murray is kindly acknowledged for the proof-reading of the paper. We would like to thank the reviewers for providing very useful comments, which helped us considerably in improving the paper.

Edited by: F. Guzzetti

Reviewed by: L. Marchi and two other referees

\section{References}

Baumann, F. and Kaiser, K. F.: The Multetta debris fan, Eastern Swiss Alps: A 500-year debris flow chronology, Arct. Antarc. Alp. Res. 31, 128-134, 1999.

Bollschweiler, M., Stoffel, M., and Schneuwly, D.: Changes of the debris-flow channels at Täschgufer since 1936, Wasser Energie Luft, 97, 218-223 (in German), 2005.

Bollschweiler, M., Stoffel, M., Ehmisch, M., and Monbaron, M.: Reconstructing spatio-temporal patterns of debris-flow activity using dendrogeomorphological methods, Geomorphology, in press, 2007.

Bovis, M. J. and Jakob, M.: The role of debris supply to determine debris flow activity in southwestern B.C., Earth Surf. Process. Landf., 24, 1039-1054, 1999.

Braam, R. R., Weiss, E. E. J., and Burrough, P. A.: Spatial and temporal analysis of mass movement using dendrochronology, Catena, 14, 573-584, 1987.

Bräker, O. U.: Measuring and data processing in tree-ring research - a methodological introduction, Dendrochronologia, 20, 203216, 2002.

Burri, M. and Marro, C.: Geological atlas of Switzerland, sheet 1345 Orsières, instruction leaflet, Hydrological and Geological Survey of Switzerland, 1993 (in French).

Burri, M., Fricker, P., Grasmück, K., Marro, C., and Oulianoff, N.: Geological atlas of Switzerland, sheet 1345 Orsières, Hydrological and Geological Survey of Switzerland, 1992 (in French).

Caine, N.: The rainfall intensity-duration control of shallow landslides and debris flows, Geogr. Ann., 62A, 23-28, 1980.

Chen, H., Dadson, S., and Yi-Guan, C.: Recent rainfall-induced landslides and debris-flows in northern Taiwan, Geomorphology, 77, 112-125, 2006.

Clague, J. J. and Evans, S. G.: A review of catastrophic drainage of moraine-dammed lakes in British Columbia, Quatern. Sci. Rev., 19, 1763-1783, 2000.

Cook, E. R. and Kairiukstis, L. A.: Methods of dendrochronology - Applications in the environmental sciences. Kluwer, London, 1990.

Corominas, J. and Moya, J.: Reconstructing recent landslide activity in relation to rainfall in the Llobregat River basin, Eastern Pyrenees, Spain, Geomorphology, 30, 79-93, 1999.

Fantucci, R. and Sorriso-Valvo, M.: Dendrogeomorphological analysis of a slope near Lago, Calabria (Italy), Geomorphology, 30, 165-174, 1999.

Gaillard, N.: Reconstruction of the debris-flow frequency on the Reuse de Saleinaz cone (VS) using dendrogeomorphological methods, Diploma Thesis, University of Fribourg, 2006 (in French).

Giardino, J. R., Shroder, J. F., and Lawson, M. P.: Tree-ring analysis of movements of a rock-glacier complex on Mount Mestas, Colorado, USA, Arct. Alp. Res., 16, 299-309, 1984. 
Hungr, O.: A model for the runout analysis of rapid flow slides debris flows and avalanches, Can. Geotech. J., 32, 610-623, 1995.

Hungr, O.: Classification and terminology, in: Debris-flow hazards and related phenomena, edited by: Jakob, M. and Hungr, O., Springer, Berlin, Heidelberg, New York, 2005

Jakob, M., Bovis, M., and Oden, M.: The significance of channel recharge rates for estimating debris-flow magnitude and frequency, Earth Surf. Process. Landf., 30, 755-766, 2005.

Labhart, T. P.: Geology of Switzerland, 6th edn., Ott-Verlag, Thun, 2004 (in German).

May, C. L. and Gresswell, R. E.: Spatial and temporal patterns of debris-flow deposition in the Oregon Coast Range, USA, Geomorphology, 57(3-4), 135-149, 2004.

Major, J. J. and Iverson, R. M.: Debris-flow deposition: effects of pore-fluid pressure and friction concentrated at flow margins, Geol. Soc. Am Bull., 111, 1424-1434, 1999.

Perret, S., Stoffel, M., and Kienholz, H.: Spatial and temporal rockfall activity in a forest stand in the Swiss Prealps - a dendrogeomorphological case study, Geomorphology, 74, 219-231, 2006.

Rapp, A. and Nyberg, R.: Alpine debris flows in Northern Scandinavia, Geogr. Ann., 63A, 183-196, 1981.

Rey, J. M. and Saameli, R.: The thunderstorms of 24th July 1996 in the Ferret/Chamonix sectors - complete analysis of the event, CRSFA, Sion, 1997 (in French).

Rinntech: LINTAB - Precision ring by ring, http://www.rinntech. com/Products/LINTAB.htm, 2006.

Santilli, M. and Pelfini, M.: Dendrogeomorphology and dating of debris flows in the Valle del Gallo, Central Alps, Italy, Dendrochronolgia, 20, 269-284, 2003.

Schweingruber, F. H.: Tree Rings and Environment, Dendroecology, Paul Haupt, Bern, Stuttgart, Wien, 1996.

Schweingruber, F. H.: Dendroecological wood anatomy, Paul Haupt, Bern, Stuttgart, Wien, 2001 (in German).

Schweingruber, F. H., Eckstein, D., Serre-Bachet F., and Bräker, O. U.: Identification, presentation and interpretation of event years and pointer years in dendrochronology, Dendrochronologia, 8, 9-39, 1990.

Shroder, J. F.: Dendrogeomorphology: review and new techniques of tree-ring dating, Prog. Phys. Geogr., 4, 161-188, 1980.

Stefanini, M. C.: Spatio-temporal analysis of a complex landslide in the Northern Apennines (Italy) by means of dendrochronology, Geomorphology, 63, 191-202, 2004.
Stoffel, M. and Beniston, M.: On the incidence of debris flows from the early Little Ice Age to a future greenhouse climate: a case study from the Swiss Alps, Geophys. Res. Lett., 33, L16404, doi:10.1029/2006GL026805, 2006.

Stoffel, M., Lièvre, I., Conus, D., Grichting, M.A., Raetzo, H., Gärtner, H. W., and Monbaron, M.: 400 years of debris flow activity and triggering weather conditions: Ritigraben, Valais, Switzerland, Arct. Antarc. Alp. Res., 37, 387-395, 2005a.

Stoffel, M., Lièvre, I., Monbaron, M., and Perret, S.: Seasonal timing of rockfall activity on a forested slope at Täschgufer (Swiss Alps) - a dendrochronological approach, Z. Geomorphol., 49, 89-106, 2005b.

Stoffel, M., Schneuwly, D., Bollschweiler, M., Lièvre, I., Delaloye, R., Myint, M., and Monbaron, M.: Analyzing rockfall activity (1600-2002) in a protection forest - a case study using dendrogeomorphology, Geomorphology, 68, 224-241, 2005c.

Stoffel, M., Bollschweiler, M., and Hassler, G. R.: Differentiating past events on a cone influenced by debris-flow and snow avalanche activity - a dendrogeomorphological approach, Earth Surf. Process. Landf., 31, 1424-1437. 2006.

Strunk, H.: Dating of geomorphological processes using dendrogeomorphological methods, Catena 31, 137-151, 1997.

Takahashi, T.: Debris Flow. Balkema Publishers, Rotterdam, 1991.

Van Steijn, H.: Debris-flow magnitude-frequency relationships for mountainous regions of Central and Northwest Europe, Geomorphology, 15, 259-273, 1996.

Varnes, D. J.: Slope movement types and processes, in: Landslides, Analysis and Control, edited by: Schuster, R. L. and Krizek, R. J., Washington, Transportation Research Board of the National Academy of Sciences, special report 176, 11-33, 1978.

Wieczorek, G. and Glade, T.: Climatic factors influencing occurrence of debris flows, in: Debris-flow hazards and related phenomena, edited by: Jakob, M. and Hungr, O., Springer. Berlin, Heidelberg, New York, 2005.

Wilkerson, F. D. and Schmid, G. L.: Debris flows in Glacier National Park, Montana: geomorphology and hazards, Geomorphology, 55, 317-328, 2003.

Wilson, R. C. and Wieczorek, G.: Rainfall thresholds for the initiation of debris flows at La Honda, California, Environ. Eng. Geosci., 1, 11-27, 1995. 